\title{
Blasting technologies for the excavation of the evacuation tunnel Vranduk II on the main road M-17
}

\author{
Ekrem Bektašević \\ "PPG" d.o.o. Sarajevo, Ph.D, ekrem.bektasevic@gmail.com \\ Hrvoje Antičević \\ "PPG" d.o.o. Sarajevo, Ph.D, anticevic.zagreb@gmail.com \\ Ferid Osmanović \\ Federal Administration for Inspection Affairs, Ph.D, ferid.osmanovic@fuzip.gov.ba \\ Sead Kadrić \\ "ZGI" d.o.o. Mostar, B.Sc (Mining), sead.kadric@gmail.com \\ Đenan Žutić \\ KPA Unicom Bosnia d.o.o. Sarajevo, B.Sc M.E., djenan.zutic@yahoo.com \\ Jakov Konta \\ West Herzegovina County, B.Sc (Mining), konta.jakov@gmail.com
}

\begin{abstract}
The Vranduk II tunnel is located on the main road route of the City of Zenica, on the main road $M-17$, section Topčić Polje - Lašva 0 with a total length of $1,062 \mathrm{~m}$. A service tube at an axial distance of 25 meters and cross passages from the service tube to the main tunnel tube (three cross passages) were excavated in parallel with the main tunnel tube. The total length of the evacuation tunnel is $856.70 \mathrm{~m}$.

Excavation works were carried out by a combination of blasting and machine excavation. The excavation was performed mainly in sedimentary rocks with the use of wedge and parallel cut. The effect of blasting with the application of wedge cut is much more suitable and appropriate for excavation in a stratified rock mass than blasting with parallel cut.
\end{abstract}

Keywords: excavation, blasting, sedimentary rock, cut

\section{Tehnologije miniranja pri iskopu evakuacijskog tunela Vranduk II na magistralnoj cesti M-17}

Sažetak: Tunel „Vranduk II“ nalazi se na glavnom putnom pravcu grada Zenice, na magistralnoj cesti M-17, dionica Topčić polje - Lašva 0 ukupne dužine $1.062 \mathrm{~m}$. Paralelno sa glavnom tunelskom cijevi, kopana je servisna cijev na osnoj udaljenosti od 25 metara i poprečni prolazi iz servisne cijevi u glavnu tunelsku cijev (III poprečna prolaza). Ukupna dužina evakuacijskog tunela iznosi 856,70 m.

Radovi na iskopu izvedeni su kombinacijom miniranja i strojnim iskopom. Iskop je vršen uglavnom u sedimentnim stijenama uz primjenu klinastog i paralelnog zaloma. Učinak miniranja uz primjenu klinastog zaloma znatno je pogodnije i primjerenije za iskop u uslojenoj stijenskoj masi od miniranja paralelnim zalomom.

Ključne riječi: iskop, miniranje, sedimentna stijena, zalom

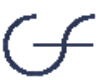


Bektašević, E., Antičević, H., Osmanović, F., Kadrić, S., Žutić, Đ., Konta, J.

Blasting technologies for the excavation of the evacuation tunnel Vranduk II on the main road

$\mathrm{M}-17$

\section{INTRODUCTION}

Excavation of the evacuation tunnel was carried out in difficult conditions due to the proximity of the constructed tunnel tube, which was under traffic. In agreement with the Client and the Supervisory Service, the traffic through the tunnel tube was closed during short periods for safety reasons during blasting for excavation of the service tunnel and cross passages. Most of the energy from the explosive charge released by blasting is consumed for destroying and crushing the rock, while a small part of the energy is converted into kinetic energy of seismic waves that propagate from the blasting site in all directions, including to the concrete lining of the constructed tunnel tube.

The passing seismic waves generate ground oscillations, or artificial earthquakes, which can cause damage to structures in the immediate vicinity. The quantitative part of the energy released by the explosion to expand gases is generally greater than the energy contained in the shock wave, but its action is concentrated in the immediate vicinity of the blast hole. The energy of the shock wave, although significantly lower, propagates as an elastic wave to the more remote environment of the blast hole and can cause undesirable effects on the rock mass and in this case on the concrete lining of the other tunnel tube.

Due to all the above, it was necessary to conduct experimental blasting and constant monitoring of blasting results in order to be able to react in time and possibly correct certain parameters of blasting.

In addition to characteristics of the rock mass, the blasting results are considerably influenced by the face area, the number, layout and length of blast holes, the quantity of explosives per ignition interval and the total amount of explosives, as well as the type of cut.

\section{GEOGRAPHICAL POSITION AND MORPHOLOGICAL CHARACTERISTICS OF THE TERRAIN}

The section of the main road M-17 Doboj - Zenica - Lašva mostly extends through the Bosna River valley, except for the section from Nemila to Zenica, where the service tunnel Vranduk II was constructed. The tunnel was constructed under the hill Zakamen with an altitude of $594.5 \mathrm{~m}$ a.s.l. The grade line level of the tunnel at the entrance portal is $287.9 \mathrm{~m}$ a.s.l., and at the end it is $296.6 \mathrm{~m}$ a.s.l. The terrain of the subject area is characterized by relatively indented mountainous relief, with altitudes ranging from about 270 to $600 \mathrm{~m}$ a.s.l., on the highest elevation, around which the Bosna River meanders in a wide arc and bypasses the town of Vranduk, maintaining the flow direction southwest - northeast. The height of overburden of the evacuation tunnel is from 4 to 200 meters. 
Bektašević, E., Antičević, H., Osmanović, F., Kadrić, S., Žutić, Đ., Konta, J.

Blasting technologies for the excavation of the evacuation tunnel Vranduk II on the main road

$\mathrm{M}-17$

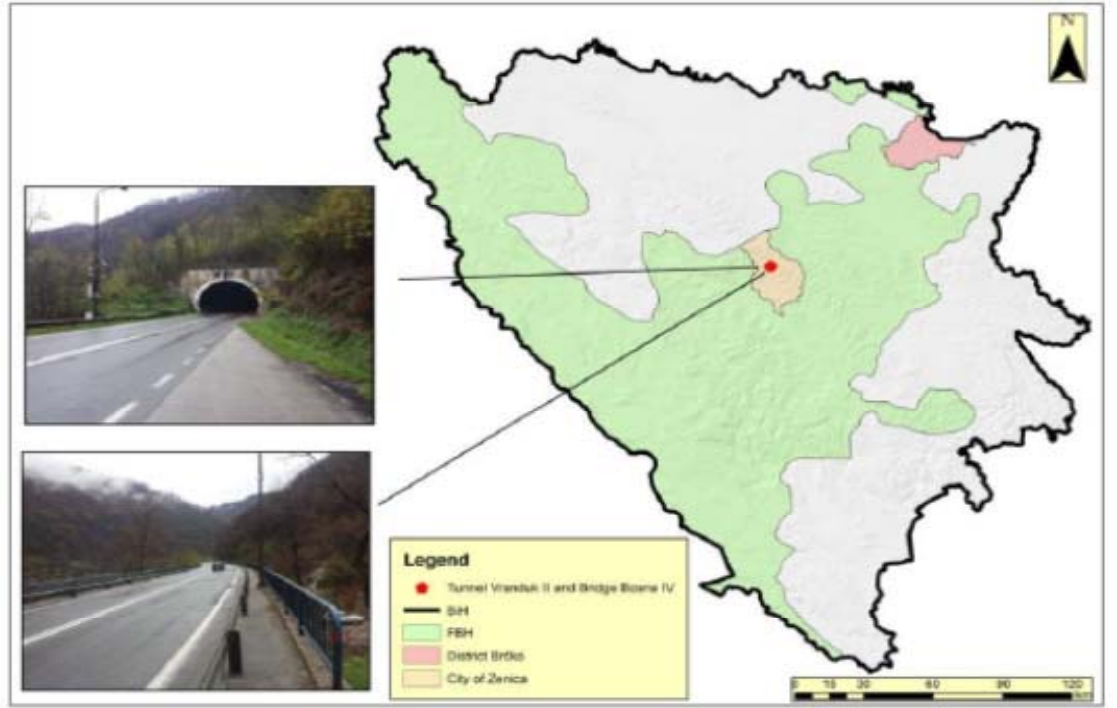

Figure 1. Geographical position of the Vranduk II tunnel

The slopes of this mountain ridge gradually descend to the valley of the Bosna River, which is also the most distinct geomorphological form in the wider area of the studied terrain. Perpendicular to the valley of the Bosna River, there are several relatively smaller ravines in which intermittent streams are formed due to heavy rainfall or melting snow. Today's form of relief is a consequence of action of overall endogenous and exogenous factors that have acted collectively or individually over a long period of time in the area under consideration.

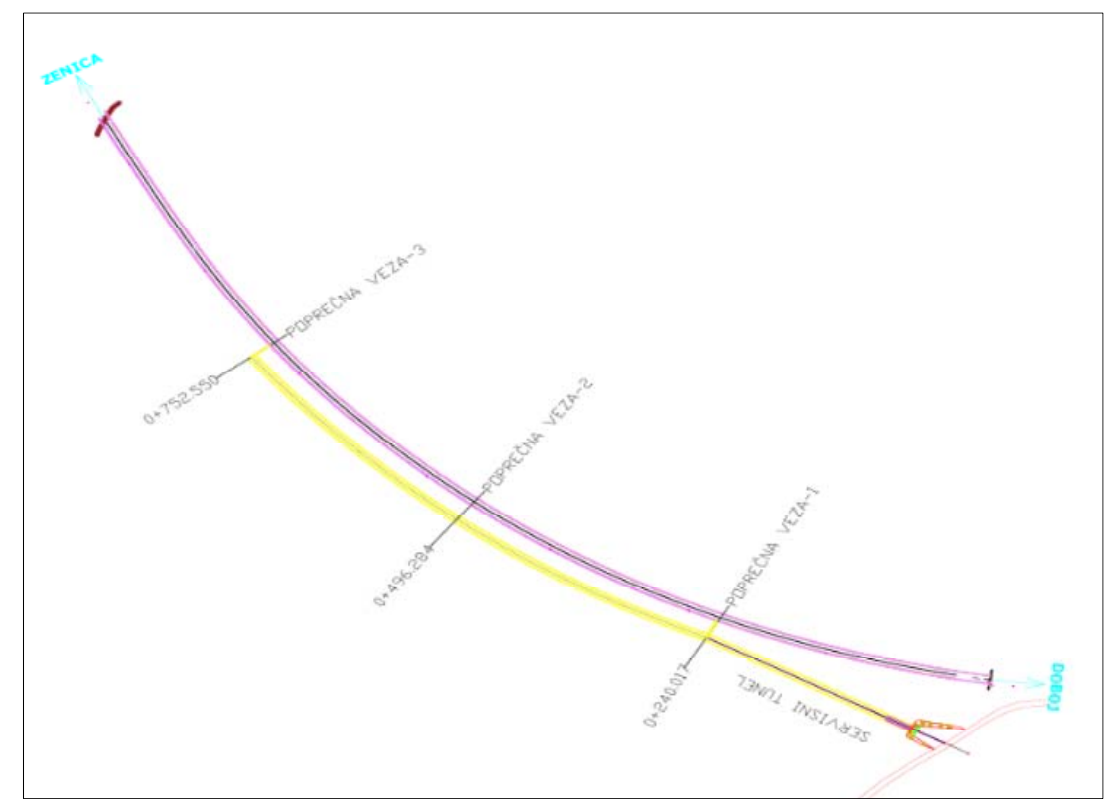

Figure 2. View of the evacuation tunnel in relation to the main tube of the tunnel Vranduk II 
Bektašević, E., Antičević, H., Osmanović, F., Kadrić, S., Žutić, Đ., Konta, J.

Blasting technologies for the excavation of the evacuation tunnel Vranduk II on the main road

M-17

\section{GEOTECHNICAL CHARACTERISTICS OF SOIL}

The rock mass test results are presented in the Main Design for the Reconstruction of the Vranduk II Tunnel. The testing was performed on 12 samples. Uniaxial strength was tested and an average value of $64 \mathrm{MPa}$ was obtained. Otherwise, the uniaxial strength ranges from 20 to $141 \mathrm{MPa}$.

The lower strength limit is characteristic of the weathering zone, so of marls and marly limestones affected by surface physical and chemical decomposition. The upper limit is characteristic of fresh unweathered marly limestones and silicified limestones, which are less commonly represented as intercalations in flysch.

\section{DRILLING AND BLASTING METHODOLOGY USED DURING CONSTRUCTION OF THE SERVICE TUBE ON THE VRANDUK II TUNNEL}

Due to the geometry of the tunnel itself, it was not possible to use standard drilling rigs for excavation of the evacuation tunnel. A drilling rig manufactured by Deilmann-Haniel Mining Systems $\mathrm{GmbH}$ was selected for drilling blast holes of appropriate length and a diameter of $\phi 41 \mathrm{~mm}$. The construction and geometry of this drilling rig made it possible to work in full profile, while taking into account all installed accompanying resources in the evacuation tunnel. The view of the drilling rig used with basic technical data is shown below.

\begin{tabular}{|c|c|c|}
\hline \multicolumn{3}{|c|}{ Technical data: } \\
\hline \multicolumn{2}{|c|}{ Manufacturer: Deilmann-Haniel Mining Systems GmbH } \\
\hline $\begin{array}{c}\text { Type: } \\
\text { Mass } \\
\text { (t): }\end{array}$ & 18.0 \\
\hline $\begin{array}{c}\text { Engine } \\
\text { power } \\
(\mathrm{kW}):\end{array}$ & 63.0 \\
\hline $\begin{array}{c}\text { Length } \\
(\mathrm{m}):\end{array}$ & 11.9 \\
\hline $\begin{array}{c}\text { Height } \\
(\mathrm{m}):\end{array}$ & 1.5 \\
\hline $\begin{array}{c}\text { Width } \\
(\mathrm{m}):\end{array}$ & 1.6 \\
\hline
\end{tabular}

Figure 3. View of the drilling rig used for drilling blast holes

The layout of blast holes by cross-sections was made based on calculations and test blasting. The depth of blast holes was determined depending on the classification of rock mass through which the tunnel was excavated and ranged from 1.5 to 2.5 meters. Safety explosives with a cartridge diameter of up to $38 \mathrm{~mm}$ were used for blasting. Explosives were initiated by electric detonators in series $0-10$. The boreholes were plugged with inert material (clay) using a wooden or plastic stick.

The electrical conductivity of the circuit was controlled with specially designed instruments (Ohmmeter). The blasting field was activated by a portable hand-held capacitor machine and a blasting cable not shorter than $75 \mathrm{~m}$. 
Bektašević, E., Antičević, H., Osmanović, F., Kadrić, S., Žutić, Đ., Konta, J.

Blasting technologies for the excavation of the evacuation tunnel Vranduk II on the main road

$\mathrm{M}-17$

\subsection{Designed drilling and blasting parameters}

All technological parameters related to blasting during the excavation of the evacuation tunnel Vranduk II were calculated through an additional mining project. The calculations were performed for the adopted cylindrical cut with an empty central borehole that is always larger in cross-section than the main borehole. The defined diameter of the central borehole in the calculation is $89 \mathrm{~mm}$. The obtained calculation results are given below for the rock classification group III because more than $80 \%$ of the evacuation tunnel was constructed in this rock group.

Calculation of the specific consumption of explosives according to Laress for the rock classification group III:

$$
\mathrm{q}=\mathrm{q}_{1} \cdot \mathrm{v} \cdot \mathrm{s} \cdot \frac{\mathrm{e}}{\mathrm{g}} \cdot \mathrm{d} \cdot \mathrm{k}\left(\frac{\mathrm{kg}}{\mathrm{m}^{3}}\right)
$$

Where:

$$
\mathrm{q}_{1}=\frac{\sigma_{\mathrm{p}}}{2000}
$$

$\sigma_{p}$ - the compressive strength of the rock massif in which the blasting is performed, based on the literature parameters ranges from 300 to $800 \mathrm{daN} / \mathrm{cm}^{2}$, for this case we adopt the value: $\sigma_{\mathrm{p}} 550 \mathrm{daN} / \mathrm{cm}^{2}$

$s$ - coefficient of rock mass structure system for conditions of massive homogeneous structure: $s=1.0$

e - coefficient of relative power of explosives calculated using the following form:

$$
\mathrm{e}=\frac{\mathrm{A}}{\mathrm{A}_{\mathrm{x}}}
$$

The coefficient of rock strength for the given conditions is:

$$
\mathrm{q}_{1}=\frac{\sigma_{\mathrm{p}}}{2000}=\frac{550}{2000}=0.28\left(\frac{\mathrm{daN}}{\mathrm{cm}^{2}}\right)
$$

The coefficient of relative power of explosives is:

$$
\mathrm{e}=\frac{\mathrm{A}}{\mathrm{A}_{\mathrm{x}}}=\frac{480}{380}=1.26
$$

By applying the Laress equation and substituting the calculated coefficient values in it, we obtain the specific consumption of explosives:

$$
q=\mathrm{q}_{1} \cdot \mathrm{v} \cdot \mathrm{s} \cdot \frac{\mathrm{e}}{\mathrm{g}} \cdot \mathrm{d} \cdot \mathrm{k}=0.28 \cdot 2.5 \cdot 1.0 \cdot \frac{1.26}{0.5} \cdot 0.9 \cdot 1=1.59\left(\frac{\mathrm{kg}}{\mathrm{m}^{3}}\right)
$$

The quantity of explosives for one blasting is calculated according to the equation:

$$
\mathrm{Q}=\mathrm{q} \cdot \mathrm{S} \cdot \mathrm{l}(\mathrm{kg})
$$


Bektašević, E., Antičević, H., Osmanović, F., Kadrić, S., Žutić, Đ., Konta, J.

Blasting technologies for the excavation of the evacuation tunnel Vranduk II on the main road

$\mathrm{M}-17$

q - specific consumption of explosives

$\mathrm{S}$ - area of the cut cross-section, in this case it is approx. $20 \mathrm{~m}^{2}$

I - length of the blast hole.

Calculation of the amount of explosives for one blasting for the rock classification group III and the length of blast holes $\mathrm{I}_{1}=1.5 \mathrm{~m}$ :

$$
\mathrm{Q}_{1.5}=\mathrm{q} \cdot \mathrm{S} \cdot \mathrm{l}=1.59 \cdot 20 \cdot 1.5=47.70(\mathrm{~kg})
$$

The number of boreholes is determined based on the selected cut and the size of cross section, and according to the equation of the Swedish tunneling method:

$$
N=(30.9+S) \cdot\left(\frac{44}{d}\right)(p c s)
$$

$\mathrm{N}$ - the number of boreholes

$S$ - area of the cut cross section

$D$ - borehole diameter, in this case: $d=41 \mathrm{~mm}$

$$
N=(30.9+S) \cdot\left(\frac{44}{d}\right)=(30.9+20) \cdot\left(\frac{44}{41}\right)=54.62(p c s)
$$

Fifty-four boreholes are adopted, noting that the number of boreholes can be increased or decreased depending on the physical and mechanical characteristics of the rock massif through which the tunnel is constructed, but with the consent and approval of the technical manager of tunneling work.

The quantity of explosives for the rock classification group III, for one blast hole (length of blast hole $1.5 \mathrm{~m}$ ) is calculated according to the following equation:

$$
\mathrm{Q}_{1}=\frac{\mathrm{Q}_{1.5}}{\mathrm{~N}}=\frac{47.70}{54}=0.88(\mathrm{~kg})
$$

The quantities of explosives and the number of blast holes were calculated based on the given equations, and the results are presented in the following table and layout scheme of blast holes during construction of the service tube in the Vranduk II tunnel in the rock massif of classification group III. 
Bektašević, E., Antičević, H., Osmanović, F., Kadrić, S., Žutić, Đ., Konta, J.

Blasting technologies for the excavation of the evacuation tunnel Vranduk II on the main road $\mathrm{M}-17$

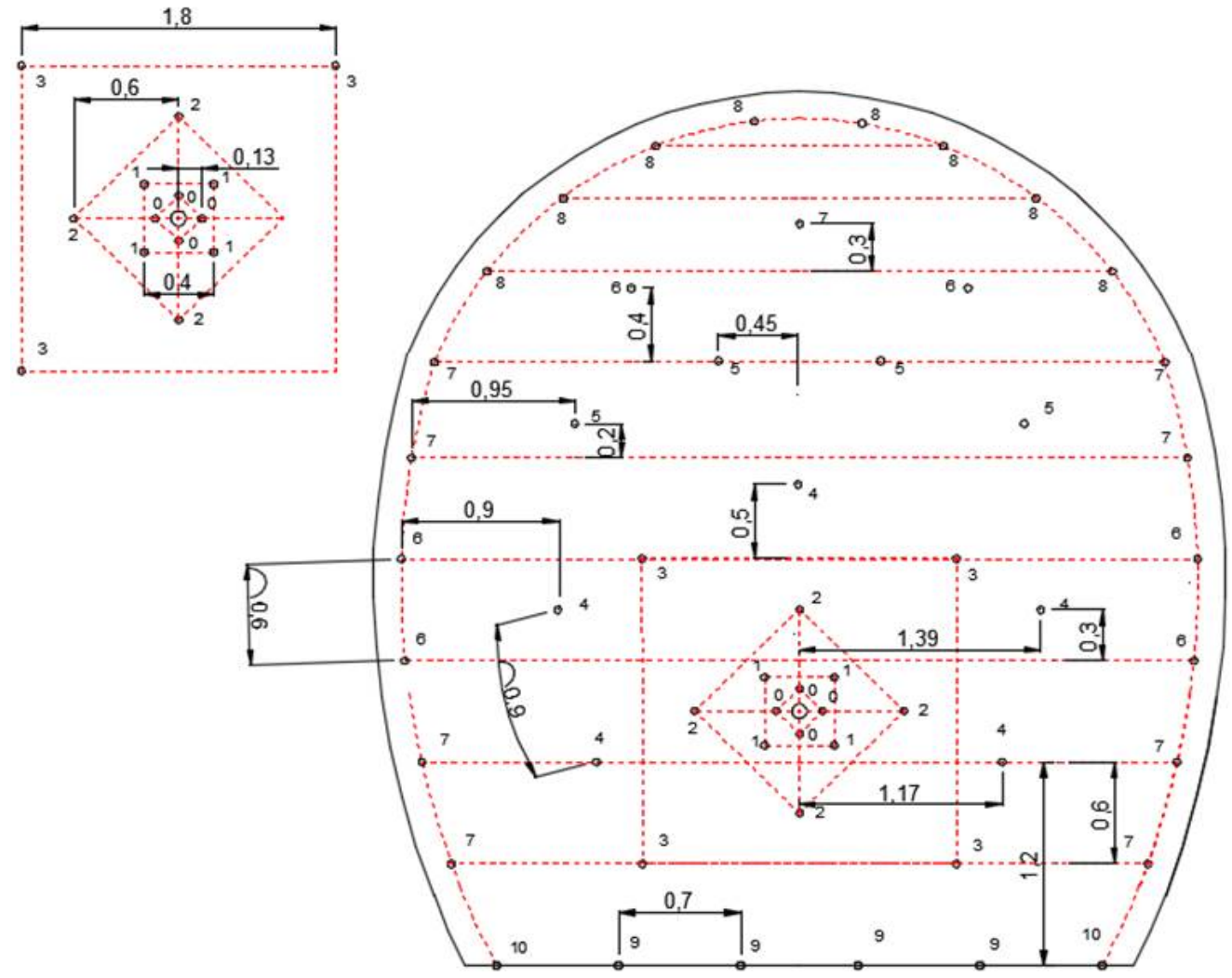

Figure 4. Layout scheme of blast holes on the cross section and layout of electric detonators by holes

Note:

- All holes on the cross section are drilled horizontally, or perpendicularly to the cross section.

- $\quad$ In Figure 4, the layout of the series of electric detonators is given by numbers 0 10.

- All electrical conductors of detonators from all blast holes on the cross section are connected in series, after which the resistance of the network is checked with Ohmmeter. 
Bektašević, E., Antičević, H., Osmanović, F., Kadrić, S., Žutić, Đ., Konta, J.

Blasting technologies for the excavation of the evacuation tunnel Vranduk II on the main road

$\mathrm{M}-17$

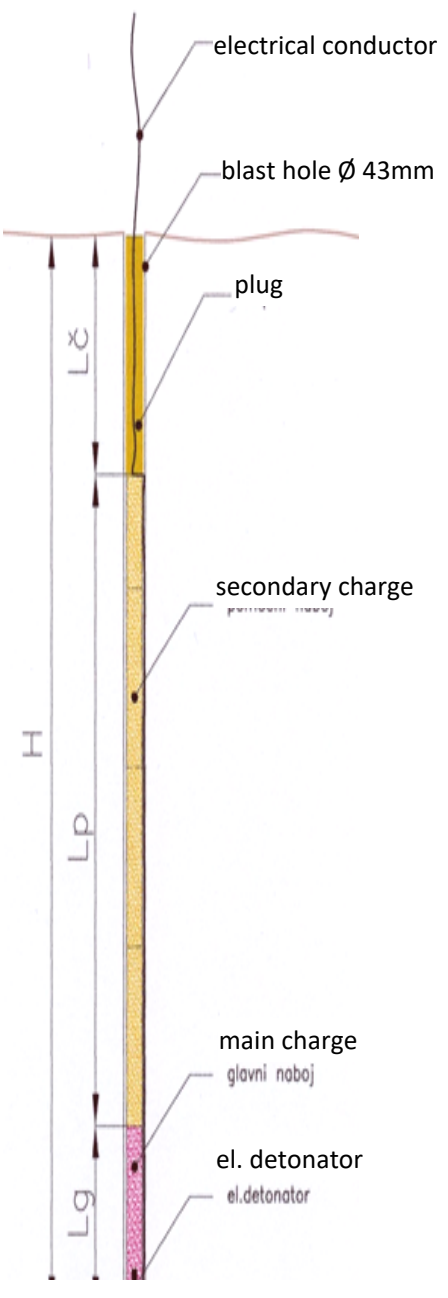

Figure 5. Structure of a blast hole

Table 1. Overview of the quantity, type of explosives and electric detonators in series by individual holes for the rock classification group III (depth of blast holes $1.5 \mathrm{~m}$ )

\begin{tabular}{|l|c|c|c|c|c|c|c|c|c|c|c|}
\hline \multicolumn{10}{|c|}{ OVERVIEW OF EXPLOSIVE QUANTITIES BY BLAST HOLES } \\
\hline Number of holes & 4 & 4 & 4 & 4 & 5 & 4 & 6 & 9 & 8 & 4 & 2 \\
\hline Total no. of holes & \multicolumn{10}{|c|}{54.00} \\
\hline Ser. el. det. & 0 & 1 & 2 & 3 & 4 & 5 & 6 & 7 & 8 & 9 & 10 \\
\hline Plastic expl. (kg) & $\begin{array}{c}0.0 \\
0\end{array}$ & 0.00 & 0.31 & 0.31 & 0.31 & 0.31 & 0.31 & 0.31 & 0.31 & 0.50 & 0.50 \\
\hline$\sum$ plast. expl. (kg) & \multicolumn{10}{|c|}{15.52} \\
\hline Powdered expl. (kg) & 0.5 & 0.7 & 0.6 & 0.6 & 0.6 & 0.6 & 0.6 & 0.6 & 0.6 & 0.6 & 0.6 \\
\hline \begin{tabular}{|c|c|c|c|c|c|c|c|c|}
\hline powd. expl. (kg) \\
\hline $\begin{array}{l}\text { expl. per hole } \\
\text { (kg/hole) }\end{array}$
\end{tabular} & $\begin{array}{c}0.5 \\
0\end{array}$ & 0.70 & 0.91 & 0.91 & 0.91 & 0.91 & 0.91 & 0.91 & 0.91 & 1.10 & 1.10 \\
\hline $\begin{array}{l}\Sigma \text { expl. for one blast. } \\
\text { (kg) }\end{array}$ & \multicolumn{10}{|c|}{47.92} \\
\hline
\end{tabular}


Bektašević, E., Antičević, H., Osmanović, F., Kadrić, S., Žutić, Đ., Konta, J.

Blasting technologies for the excavation of the evacuation tunnel Vranduk II on the main road

$\mathrm{M}-17$

The total time required to drill the planned number of blast holes (depth of blast holes $1.5 \mathrm{~m})$ is:

$$
t_{b}=\frac{N \cdot l}{60 \cdot n \cdot V_{b} \cdot k}=\frac{54 \cdot 150}{60 \cdot 1 \cdot 150 \cdot 0.01}=90.00 \text { minutes }
$$

The total time required to prepare an explosive charge of blast holes $1.5 \mathrm{~m}$ long is:

$$
t_{p}=\frac{N \cdot t \cdot 0}{n}=\frac{54 \cdot 2 \cdot 1.0}{2}=54.00 \min \text {. }
$$

At the very beginning of blasting works in classification group III, test blasting was performed to check the technical parameters given in the blasting design for the same depth of blast holes $(1.5 \mathrm{~m})$ with the use of parallel cylindrical cut, as well as wedge cut. The basic characteristics of the explosives used during blasting are given below:

Table 2. Overview of electric detonators used during excavation of the evacuation tunnel

\begin{tabular}{|c|c|c|c|c|c|c|c|c|c|c|c|}
\hline $\begin{array}{c}\text { Serial electric detonator } \\
\text { marked on the sketch }\end{array}$ & 0 & 1 & 2 & 3 & 4 & 5 & 6 & 7 & 8 & 9 & 10 \\
\hline Delay (ms) & 0 & 34 & 68 & 102 & 250 & 750 & 1500 & 2000 & 3000 & 4000 & 5000 \\
\hline
\end{tabular}

Table 3. Overview of basic characteristics of explosives used during tunnel excavation

\begin{tabular}{|l|c|c|c|}
\hline $\begin{array}{c}\text { Characteristics of } \\
\text { explosives used }\end{array}$ & $\begin{array}{c}\text { Plastic } \\
\text { explosive }\end{array}$ & $\begin{array}{c}\text { Contour } \\
\text { explosive }\end{array}$ & $\begin{array}{c}\text { Powdered } \\
\text { explosive }\end{array}$ \\
\hline Density $\left(\mathrm{kg} / \mathrm{dm}^{3}\right)$ & 1.50 & 1.18 & 1.08 \\
\hline Operating capacity $\left(\mathrm{cm}^{3}\right)$ & 390 & 385 & 380 \\
\hline Explosion energy $(\mathrm{KJ} / \mathrm{kg})$ & 4200 & 4200 & 4056 \\
\hline Cartridge diameter $(\mathrm{mm})$ & 38.00 & 22.00 & 38.00 \\
\hline Cartridge length $(\mathrm{mm})$ & 200.00 & 500.00 & 190.00 \\
\hline Cartridge weight $(\mathrm{kg})$ & 0.313 & 0.208 & 0.20 \\
\hline
\end{tabular}

After the test blasting was conducted, the obtained parameters (seismicity, distance of structures, progress, contour quality, granulation, drilling and filling scheme, initiation method, plugging, type of explosives, etc.) were analyzed and minor corrections to blast hole layout schemes, minor correction of explosives, and correction of delay intervals by individual blast holes were made. The choice of the type of explosive plays a decisive role in the performance of blasting (the relationship between shock wave energy and gas expansion). It is important to note that there were no major deviations in the consumption of explosives per step during blasting compared to the designed quantity.

The layout schemes of blast holes on the cross section for both types of cuts (cylindrical and parallel), as well as the optimum quantities of explosives per blast holes obtained after the test blasting are presented in the continuation of the paper. 
Bektašević, E., Antičević, H., Osmanović, F., Kadrić, S., Žutić, Đ., Konta, J.

Blasting technologies for the excavation of the evacuation tunnel Vranduk II on the main road

$\mathrm{M}-17$

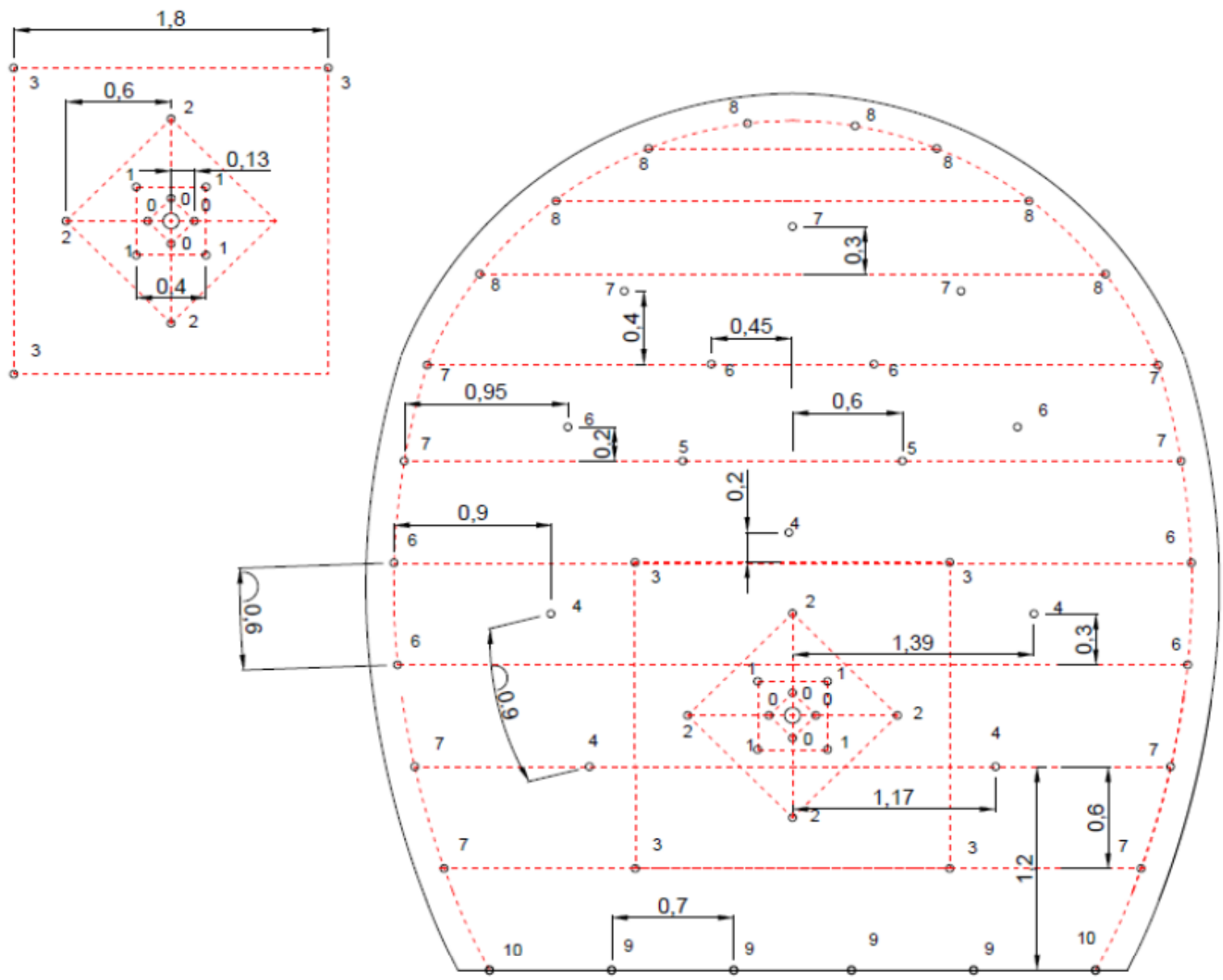

Figure 6. Blast hole layout scheme on the cross section with parallel cylindrical cut and layout of electric detonators by blast holes

Table 4. Overview of the quantity and type of explosives and electric detonators in series by individual blast holes for the rock classification group III (1.5 m - depth of blast holes)

\begin{tabular}{|c|c|c|c|c|c|c|c|c|c|c|c|}
\hline \multicolumn{12}{|c|}{ OVERVIEW OF EXPLOSIVE QUANTITIES BY BLAST HOLES } \\
\hline Number of blast holes & 4 & 4 & 4 & 4 & 5 & 2 & 8 & 11 & 8 & 4 & 2 \\
\hline Total number of holes & \multicolumn{11}{|c|}{56} \\
\hline Ser. el. det. & 0 & 1 & 2 & 3 & 4 & 5 & 6 & 7 & 8 & 9 & 10 \\
\hline Plastic expl. (kg/hole) & 0.31 & 0.31 & 0.31 & 0.31 & 0.31 & 0.31 & 0.31 & 0.1 & 0.1 & 0.63 & 0.63 \\
\hline$\Sigma$ plast. expl. $(\mathrm{kg})$ & \multicolumn{11}{|c|}{15.29} \\
\hline Contour expl.(kg/hole) & 0 & 0 & 0 & 0 & 0 & 0 & 0 & 0.7 & 0.7 & 0 & 0 \\
\hline$\sum$ powd. expl. $(\mathrm{kg})$ & \multicolumn{11}{|c|}{13.3} \\
\hline Powd. expl. (kg/hole) & 0 & 0 & 0.8 & 0.6 & 0.6 & 0.6 & 0.6 & 0.1 & 0 & 0.6 & 0.6 \\
\hline$\sum$ powd. expl. (kg) & \multicolumn{11}{|c|}{19.3} \\
\hline $\begin{array}{l}\sum_{(\mathrm{kg} / \mathrm{hole})}^{\text {expl. }} \text { per hole } \\
\end{array}$ & 0.31 & 0.31 & 1.11 & 0.91 & 0.91 & 0.91 & 0.91 & 0.9 & 0.8 & 1.23 & 1.23 \\
\hline $\begin{array}{l}\sum_{(\mathrm{kg})} \text { expl. for one blast. } \\
\end{array}$ & \multicolumn{11}{|c|}{47.89} \\
\hline
\end{tabular}


Bektašević, E., Antičević, H., Osmanović, F., Kadrić, S., Žutić, Đ., Konta, J.

Blasting technologies for the excavation of the evacuation tunnel Vranduk II on the main road

M-17

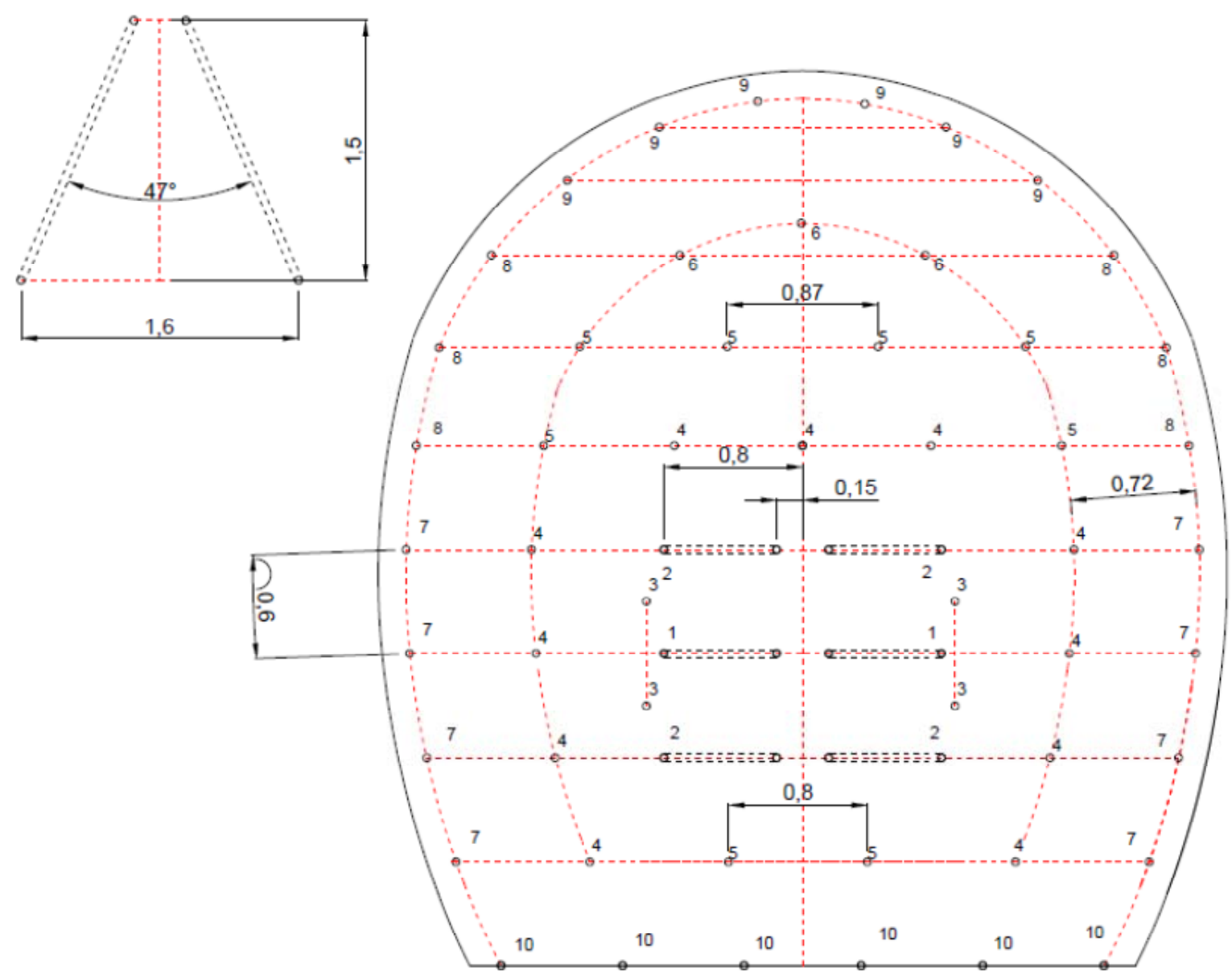

Figure 7. Blast hole layout scheme on the cross section with wedge cut and layout of electric detonators by blast holes

Table 5. Overview of the quantity and type of explosives and electric detonators in series by individual blast holes for the rock classification group III (1.5 $\mathrm{m}$ - depth of blast holes)

\begin{tabular}{|c|c|c|c|c|c|c|c|c|c|c|}
\hline \multicolumn{11}{|c|}{ OVERVIEW OF EXPLOSIVE QUANTITIES BY BLAST HOLES - WEDGE CUT } \\
\hline Number of blast holes & 2 & 4 & 4 & 11 & 8 & 3 & 8 & 6 & 6 & 6 \\
\hline Total number of holes & \multicolumn{10}{|c|}{58} \\
\hline Ser. el. det. on sketch & 1 & 2 & 3 & 4 & 5 & 6 & 7 & 8 & 9 & 10 \\
\hline Plastic expl. (kg) & 0.62 & 0.62 & 0.62 & 0.31 & 0.31 & 0.31 & 0.1 & 0.1 & 0.1 & 0.62 \\
\hline$\sum$ plast. expl. (kg) & \multicolumn{10}{|c|}{18.74} \\
\hline Contour expl. (kg) & 0 & 0 & 0 & 0 & 0 & 0 & 0.7 & 0.7 & 0.7 & 0 \\
\hline$\Sigma$ powd. expl. (kg) & \multicolumn{10}{|c|}{14} \\
\hline Powdered expl. (kg) & 0.4 & 0.2 & 0.2 & 0.5 & 0.5 & 0.5 & 0 & 0 & 0 & 0.4 \\
\hline$\sum$ powd. expl. (kg) & \multicolumn{10}{|c|}{15.8} \\
\hline $\begin{array}{l}\sum_{(\mathrm{kg} / \mathrm{hole})}^{\text {expl. }} \text { per hole } \\
\end{array}$ & 1.02 & 0.82 & 0.82 & 0.81 & 0.81 & 0.81 & 0.8 & 0.8 & 0.8 & 1.02 \\
\hline $\begin{array}{l}\sum_{(\mathrm{kg})} \text { expl. for one blast. } \\
\end{array}$ & \multicolumn{10}{|c|}{48.54} \\
\hline
\end{tabular}


Bektašević, E., Antičević, H., Osmanović, F., Kadrić, S., Žutić, Đ., Konta, J.

Blasting technologies for the excavation of the evacuation tunnel Vranduk II on the main road

$\mathrm{M}-17$

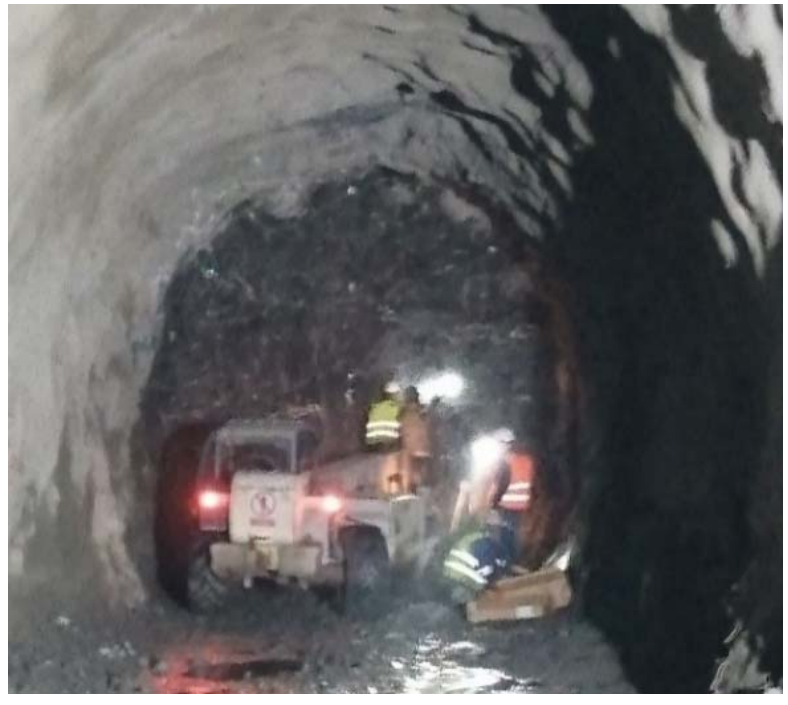

Figure 8. Filling of blast holes

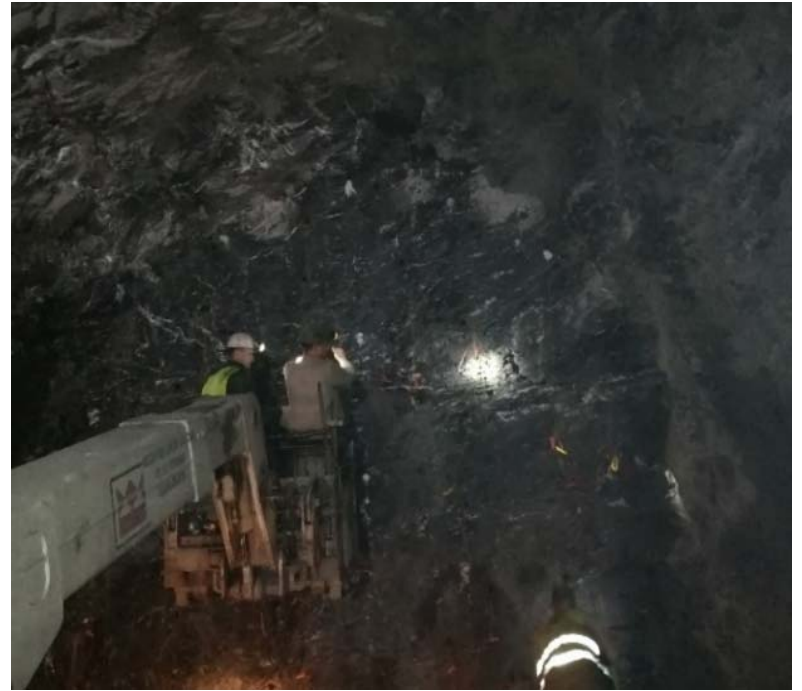

Figure 9. Connecting of blast holes

\section{COMPARISON OF PARALLEL AND WEDGE CUT BLASTING}

Excavation of the evacuation tunnel Vranduk II was performed mainly in a stratified rock mass with similar physical and mechanical properties, and since there were differences in blasting technology during the excavation, a comparison of the results provides an insight into the effectiveness of applied technologies.

As evident from Tables 4 and 5, the parameters obtained when conducting test blasting during excavation of the evacuation tunnel Vranduk II, both applied cuts require approximately the same amount of explosives for holes $1.5 \mathrm{~m}$ deep and approximately the same number of blast holes.

Parallel cut blasting is characterized by the gradient of blast holes being defined by the tunnel axis to which all blast holes are parallel. This type of blasting does not take into account the structural and textural characteristics of the rock mass. As all blast holes are parallel to each other, drilling them requires high precision. If the drilling results in a deviation from the specified direction of blast holes, it significantly affects the blasting results, and after blasting part of the holes on the face of the work surface remains uncut $(20-30 \mathrm{~cm})$, which causes higher specific consumption of explosives in relation to the cut rock mass.

Wedge cut blasting is characterized by the cutting holes forming a wedge, and the gradient of the wedge can be adjusted to discontinuities in the rock mass. Such adjustment of the wedge gradient and the use of weakened directions in the rock improves the results of blasting and increases efficiency. For blasting with wedge cut, drilling of cutting holes is somewhat more complex, especially in tunnel tubes with a smaller width. It can be concluded that the wedge cut is hardly applicable or not applicable at all in tunnel tubes of smaller width with a step of advancement of more than $1.5 \mathrm{~m}$, and in such cases a parallel cylindrical cut (for a step of advancement of 2-3 $\mathrm{m}$ ) is used. 
Bektašević, E., Antičević, H., Osmanović, F., Kadrić, S., Žutić, Đ., Konta, J.

Blasting technologies for the excavation of the evacuation tunnel Vranduk II on the main road

M-17

\section{CONCLUSION}

Blasting in the service tube and cross passages can have negative consequences on the support system and concrete lining of the tunnel tube in traffic. Interference of the pressure shock wave and the pressure shock wave reflected from the free surface can cause damage, by loosening parts of support of the constructed tunnel.

One should bear in mind that, unlike above-ground blasting, blasting in tunnels, or underground blasting, is limited in options of operation method, because of the high fixity of one free surface.

Determining the type and quantity of explosives by the level of ignition and the method of blasting is crucial for the step of advancement and the magnitude of seismic impact of blasting.

Inappropriate quantity of explosives, as well as incorrect choice of blasting method can increase the seismic impact and reduce the step of advancement. In most cases, in order to reduce the impact of blasting, it is recommended to reduce explosives by the level of ignition. However, care should be taken when reducing the quantity of explosives, because all the energy that is not consumed for crushing and destruction propagates further in the form of elastic waves, which causes increased ground vibrations. For this reason, when reducing the quantity of explosives, it is necessary to maintain the density of charge, which means that the reduction of explosives should be proportional to the reduction of drilling depth (progress).

Blasting for the purpose of just loosening the rock mass should be avoided because this way of blasting can cause large vibrations of the ground in relation to the amount of explosives consumed. Also, it is necessary to identify the occurrence of seepage water, the presence of which causes seismic growth. It may happen that seepage water does not occur during measurements, but it may occur after the parameters for the blasting process are adopted.

Test blasting with seismic measurements must be performed as frequently as possible, especially when the geological structure of the rock mass changes in order to confirm the existing, and to define new parameters of blasting, as necessary.

The advantages of wedge cut compared to parallel cut are the following: fewer blast holes (cut), saving time on drilling and good results for up to $3.8 \mathrm{~m}$ of drilling (for greater depths the material cannot be removed and then over a meter-deep pockets remain). It is necessary to check whether there is enough space for drilling at an angle because of the length of the drill carriage. Parallel cut is used for greater drilling depths, which require a reliable operator or computerized drill.

\section{REFERENCES}

1. Supplementary mining project of excavation and ventilation during construction of the service tube of the Vranduk tunnel, Main road M-17; E73, Vareš, March 2019

2. Jovanović P.: „Izrada podzemnih prostorija velikog profila“, Građevinska knjiga, Beograd, 1984.

3. Antičević H., Dobrilović M., Perković H.: „Zona oštećenja stijenske mase pri iskopu tunela miniranjem", Rudarsko-geološko-naftni zbornik, Originalni znanstveni rad, Zagreb, 2012.

4. Karlovac Z.: "Blasting during the excavation of the Cardak tunnel on the Rijeka - Zagreb motorway ", FMGPE Zagreb, Seminar paper, 2008.

5. Langefors U. \& Kihlstrom B.: "The modern technique of rock blasting", Wiley, New York, 1978. 